\title{
RICE FARMERS' PERCEPTION AND KNOWLEDGE OF INTEGRATED RICE AND FISH FARMING IN SELECTED LOCAL GOVERNMENT AREAS OF KWARA STATE
}

\author{
Deborah OLABODE ${ }^{1, *}$, Kemi OMOTESHO ${ }^{1}$, Oluwafemi OLABANJI ${ }^{1}$, \\ Israel OGUNLADE ${ }^{1}$, Oluwatosin ADEBISI ${ }^{1}$
}

^E-mail: olabodedeb@gmail.com

Received: Oct. 08, 2020. Revised: Dec. 18, 2020. Accepted: Dec. 24, 2020. Published online: Jan. 29, 2021

\begin{abstract}
In spite of the numerous advantages associated with integrated rice and fish farming, deliberate adoption of this technique is still insignificant. This study examined rice farmers' perception and knowledge of integrated rice and fish farming practice in Kwara State. A threestage sampling procedure was used to select 149 rice farmers, while data was obtained through the use of a wellstructured structured interview schedule. Data were analysed using descriptive statistics and the Pearson's Product Moment Correlation (PPMC). The results show that $81.9 \%$ of the respondents were male with mean age of 38 years and an average of 14 years farming experience. Given the average mean score of 3.04 respondents had a positive perception of integrated rice and fish farming, while $63.8 \%$ of the respondents had moderate knowledge. Farmers' identified high cost of irrigation materials (M.S.=2.59), poaching (M.S.=2.59), flooding (M.S.=
\end{abstract}

2.55) as major constraints to the practice of integrated rice and fish farming. Farmers' perception had a significant relationship with knowledge of integrated rice and fish farming at $p<0.05$ level. Also, farmers' age $(\mathrm{r}=0.300, p<0.000)$, level of education ( $\mathrm{r}=0.287, p<0.000)$, farming experience $(\mathrm{r}=0.220, p<0.007)$, membership of cooperative society $(\mathrm{r}=0.176, p<0.032)$ and extension contact $(\mathrm{r}=0.204, \quad p<0.013)$ had significant relationship with the knowledge level. The study concluded that the rice farmers had moderate knowledge and positive perception of integrated rice and fish farming. There is a need to provide incentives, such as irrigation facilities to farmers and provision of adequate training on integrated rice and fish farming in order to fully maximize the potentials therein.

Keywords: perception; knowledge; integrated farming; rice; fish.

\footnotetext{
${ }^{1}$ Department of Agricultural Extension and Rural Development, University of Ilorin, Nigeria
} 


\section{INTRODUCTION}

Globally, food security and poverty alleviation are subjects of deliberations intricately linked to agriculture. In Nigeria, regardless of the abundant crude oil reserve, agriculture plays an important role in economic development and sustenance of the populace (Odetola and Etumnu 2013). The agricultural sector supports the livelihood of rural farming households through crop and animal production activities. According to the World Bank (2017), the nation's economy experienced strong economic growth over the last decade driven by agriculture, yet poverty remained significant as more than 50 percent of Nigerians live below the poverty line of US $\$ 1.25$ per day. Oyekale et al. (2012), Adekoya (2014) and Enimu (2018) also observed that, poverty and food insecurity are still widespread in Nigeria and particularly amongst rural farming households.

The economic recession experienced in the country has further heightened this situation, hence the need for alternative sources of additional income by resource poor farmers. Agyeman et al. (2014) noted that diversifying rural livelihood activities within and outside the farm sector by smallholder farmers in developing nations could address income and food security shortfalls. Considering the risks associated with farming in Nigeria, integrated farming is an ideal option for small-holders farmers in rural areas to diversify income. Ellis (2000) described income diversification as the process by which rural households construct an increasingly diverse portfolio of activities and assets in order to survive and to improve their standard of living.

Integrated farming involves the combination of two or more separate farming systems concurrently or alternately as a part of the whole farming system. The major feature being recycling of waste products such that the waste of one system becomes the input of the other system. Integrated rice and fish farming is a type of integrated farming system, which combines fish culture with rice production and thus promotes efficient utilization of production resources. Essentially, rice and fish are key components for global food security, and the main carbohydrate and protein source of more than $50 \%$ of the world populace, especially the rural poor households (Rahman, 2016). Considering the risks associated with rice farming in Nigeria (Omotesho et al., 2017) and the need to increase production of both rice and fish in the face of ever increasing population, integrated rice and fish farming is a viable option to address these challenges.

Although, when compared with rice monoculture, the cost of rice cum fish production is higher, but the benefits outweigh the costs. Integrating rice with fish production has numerous economic and ecological advantage, such as: increased rice and fish yield 
(Vromant et al., 2002); environmental protection (Oribhabor and Ansa 2006); increased income (Gabriel et al., 2007); weed and pest control (Frei and Becker 2005). In spite of these numerous advantages associated with integrated rice fish farming, and availability of requisite resources, deliberate adoption of the technique is still insignificant.

The perception of farmers has been one of the significant components used to evaluate technological adoption, its feedback, and management efficiency of farmers (Abdul-Gafar et al., 2016). In addition, socio-economic characteristics of farmers have been reported to influence their knowledge of, and attitude to agricultural practices (Adesope et al., 2012).

Therefore, this study examined rice farmers' perception and knowledge of integrated rice and fish farming. Specifically, the study determined their perception and examined their knowledge of integrated rice and fish farming practices. It also identified the constraints to the practice of integrated rice and fish farming. The following hypotheses were formulated and tested:

$\mathrm{HO}_{1}$ : There is no significant relationship between rice farmers' socio-economic characteristics and their knowledge level of integrated rice and fish farming;

$\mathrm{HO}_{2}$ : There is no significant relationship between the knowledge and the perception of rice farmers on integrated rice and fish farming.

\section{MATERIALS AND METHODS}

\section{Study area}

The study was conducted in Kwara State, Nigeria. It has a land area of about $32,500 \mathrm{~km}^{2}$ and a population of 2,371,089, according to the 2006 National Population Census figures. This is projected to be 3,192,893 in 2017 (NBS, 2018) It is located between latitudes $7^{\circ} 45^{\prime} \mathrm{N}$ and $9^{\circ} 30^{\prime} \mathrm{N}$ and longitudes $2^{\circ} 30^{\prime} \mathrm{E}$ and $6^{\circ} 25^{\prime} \mathrm{E}$, its topography is mainly plain to slight gentle rolling lands. The annual rainfall ranges between $800 \mathrm{~mm}$ and 1500 mm (Oladimeji and Abdulsalam, 2013) and average temperature ranges between $30^{\circ} \mathrm{C}$ and $35^{\circ} \mathrm{C}$. Some parts of Kwara state are located along the river Niger basin and the populace engages in water related activities, such as rice cultivation and captural fishing. Hence according to the 2015 agricultural production survey, Kwara state was named amongst eighteen states in Nigeria that contributed to national rice production.

\section{Sampling technique and sample size}

The population for the study comprise all rice farmers in Kwara State. A three stage sampling procedure was used to select 149 rice farmers. Kwara State is divided into four zones based on agro-ecological characteristics. The first stage involved the selection of Zone B out of the four zones because the bulk of rice production takes place in this area (Fakayode et al., 2010). The zone comprises Edu and Patigi local government areas. Rice cultivation and fishing is the major source of livelihood because of the proximity to the bank of river Niger. The second stage involved a simple random sampling of $50 \%$ rice farmer groups from both local government areas. The third stage involved the random selection of $50 \%$ of 


\section{RICE FARMERS' PERCEPTION AND KNOWLEDGE OF INTEGRATED RICE AND FISH FARMING}

members in each group giving a total sample size of 149 rice farmers.

\section{Data collection and analysis}

Data was collected with the aid of a structured interview schedule. Descriptive statistics involving frequency distribution, percentages and means were used for data analysis and presentation. Farmers' perception on integrated rice and fish farming practices was measured using a 4 point Likert scale, graduated as: 1 strongly disagree, 2 - disagree, 3 - agree, 4 - strongly agree. A number of 20 statements carefully constructed to depict respondents' perception of integrated rice and fish farming were presented to the respondents. Individual mean score was taken as a measure of their perception. The mean of the response values, which is 2.5, was taken as the cut-off point such that respondents with mean score of 2.5 and above were regarded as having positive perception, while those with mean score of below 2.5 were regarded as possessing a negative perception. To test knowledge of integrated rice and fish farming, respondents were presented with a list comprising 20 questions on integrated rice and fish farming. The scoring guide was 1 for each correct answer and 0 for any wrong answer. The highest score obtainable was 20 and the lowest score was zero. Respondents with scores more than or equal to 15 points were considered as possessing a high knowledge level integrated rice and fish farming, those with more than or equal to 10 points, but less than 15 points were considered as possessing a moderate knowledge level, while those with less than 10 points were considered as possessing a low knowledge level of integrated rice and fish farming. The constraints to integrated rice and fish farming was measured using a 3 point Likert type scale. The scale was graduated as: 1 - not a constraint, 2 - severe, 3 very severe. A number of 12 constraints to the practice of Integrated Rice and Fish Farming was listed and measured using a 3 point Likert type scale: 3 - very serious, 2 - serious, 1 - not a constraint. The mean score for each item listed was calculated, the mean of the response values, which is 2.0, was taken as the cut- off point, such that constraint items with mean score equal to or greater than 2.0 were regarded as severe, while those with mean score less than 2.0 were regarded as less severe constraints. Pearson's Product Moment Correlation (PPMC) was used to test the hypotheses of the study.

\section{RESULTS AND DISCUSSION}

\section{Socio-economic characteristics of the respondents}

This section discusses the socioeconomic characteristics of the respondents. The results are as summarized in Table 1.

The result in Table 1 shows that $73.8 \%$ of the respondents were within the youthful age, with an average of 38 years. This implies that majority of the respondents were young and agile, this is an important asset for efficient production and susceptibility to change. This finding supports that Oladimeji and Abdulsalam (2013), who reported that farmers in Northern part of Kwara State were middle aged. The majority $(81.9 \%)$ of the respondents were male, while $18.7 \%$ are female. This result indicates that there are more male rice farmers than female. The plausible reason could be due to the rigour associated with rice production. 
D.A. OLABODE, K.F. OMOTESHO, O.P. OLABANJI, I. OGUNLADE, O.O. ADEBISI

Table 1 - Distribution of respondents according to their socio-economic characteristics

\begin{tabular}{|c|c|c|c|c|}
\hline Variables & Frequency & Percentages & Mean & SD \\
\hline \multicolumn{5}{|l|}{ Age (in years) } \\
\hline$\leq 30$ & 52 & 34.9 & & \\
\hline $31-45$ & 58 & 38.9 & 38.03 & 13.78 \\
\hline $46-60$ & 22 & 14.8 & & \\
\hline$\geq 61$ & 17 & 11.4 & & \\
\hline \multicolumn{5}{|l|}{ Sex } \\
\hline Male & 122 & 81.9 & & \\
\hline Female & 27 & 18.1 & & \\
\hline \multicolumn{5}{|l|}{ Religion } \\
\hline Islam & 124 & 83.2 & & \\
\hline Christianity & 25 & 16.8 & & \\
\hline \multicolumn{5}{|l|}{ Marital status } \\
\hline Married & 112 & 75.2 & & \\
\hline Otherwise & 37 & 24.8 & & \\
\hline \multicolumn{5}{|l|}{ Level of education } \\
\hline No formal education & 11 & 7.4 & & \\
\hline Primary education & 13 & 8.7 & & \\
\hline Secondary education & 101 & 67.8 & & \\
\hline Tertiary education & 24 & 16.1 & & \\
\hline \multicolumn{5}{|l|}{ Primary occupation } \\
\hline Farming & 96 & 64.4 & & \\
\hline Otherwise & 53 & 35.6 & & \\
\hline \multicolumn{5}{|l|}{ Farm size (acres) } \\
\hline$<5$ & 53 & 35.6 & & \\
\hline 10 May & 67 & 44.9 & 5.1 & 4.3 \\
\hline$>10$ & 29 & 19.5 & & \\
\hline \multicolumn{5}{|l|}{ Household size } \\
\hline$\leq 5$ & 59 & 39.6 & & \\
\hline 10 Jun & 39 & 26.2 & 8.3 & 5.7 \\
\hline $15 \mathrm{Nov}$ & 38 & 25.5 & & \\
\hline$\geq 16$ & 13 & 8.7 & & \\
\hline \multicolumn{5}{|l|}{ Farming experience } \\
\hline$\leq 5$ & 34 & 22.8 & & \\
\hline 15 Jun & 63 & 42.3 & 13.8 & 9.4 \\
\hline $16-25$ & 33 & 22.1 & & \\
\hline$\geq 26$ & 19 & 12.8 & & \\
\hline \multicolumn{5}{|c|}{ Membership of cooperative society } \\
\hline Yes & 105 & 70.5 & & \\
\hline No & 44 & 29.5 & & \\
\hline \multicolumn{5}{|c|}{ Extension contact (one year) } \\
\hline 0 & 42 & 28.2 & & \\
\hline
\end{tabular}


RICE FARMERS' PERCEPTION AND KNOWLEDGE OF INTEGRATED RICE AND FISH FARMING

\begin{tabular}{lllll}
\hline 4 Jan & 63 & 42.3 & 3.8 & 4.3 \\
\hline 8 May & 17 & 11.4 & & \\
\hline$>=9$ & 27 & 18.1 & & \\
\hline Source of information on IRFF & & & & \\
\hline Extension agents & 35 & 23.5 & \\
\hline Radio & 54 & 36.2 & \\
\hline Television & 14 & 9.4 & \\
\hline Cooperative societies & 20 & 13.4 & \\
\hline Friends and relatives & 15 & 10.1 & \\
\hline Others & 11 & 7.4 & \\
\hline
\end{tabular}

Source: Field Survey, 2018; *IRFF: Integrated Rice and Fish Farming

Results in Table 1 shows that majority of the respondents $(75.2 \%)$ were married, $92.6 \%$ had formal education at varied levels. The result indicates that majority of the farmers were responsible and literate which could influence their perception and adoption of integrated rice and fish farming. This result corroborates the findings of Ayinde et al. (2016) that majority of rice farmers in Kwara state had one form of formal education. Majority of the respondents (64.4\%) had farming as their primary occupation, while $35.6 \%$ combined farming with other businesses and artisanal fishery. This result shows that most of the respondents were fulltime farmers and depended solely on farming. This implies that farmers' income was less diversified and hence prone to risk. Less than $20 \%$ of the respondent had farmlands of greater than 10 acres, while majority (80.6\%) had farmlands of less than 10 acres. The result indicates that majority of the respondents were smallholder farmers and income diversification could likely raise their standards of living. The mean number of years of farming experience was 13.8 years with 42.3\% having between 6-15 years of farming experience. This result indicates that rice farming was an age long profession among the respondents and this implies that farmers were familiar with the nitty gritty of rice production. Majority of the respondents (70.5\%) as shown in Table 1 were members of cooperative societies. Membership of cooperative society could enable the rice farmers' access to information and fund required to start integrated rice and fish farming. More than $50 \%$ of the respondents had between one to eight contacts with extension agents per annum and on the average farmers had four contacts with extension within a year. This could be due to focus government concerted effort at different levels to increase production and reduce dependence on importation.

\section{Perception of integrated rice and fish farming practices}

This section discusses respondents' perception of integrated rice and fish farming. The results are as summarized in Table 2. 
Table 2 - Distribution of respondents based on their perception of Integrated Rice and Fish Farming

\begin{tabular}{|c|c|c|c|c|c|c|}
\hline Likert items & $\begin{array}{l}\text { S.A. } \\
F(\%)\end{array}$ & $\begin{array}{c}A \\
F(\%)\end{array}$ & $\begin{array}{c}D \\
F(\%)\end{array}$ & $\begin{array}{l}\text { S.D. } \\
\text { F(\%) }\end{array}$ & Score & M.S. \\
\hline $\begin{array}{l}\text { Integrated rice and } \\
\text { fish farming reduce } \\
\text { waste disposal by } \\
\text { recycling organic } \\
\text { waste from fish for } \\
\text { rice production }\end{array}$ & $64(43)$ & $70(47)$ & $10(6.7)$ & $5(3.4)$ & 491 & 3.29 \\
\hline $\begin{array}{l}\text { Integrated rice and } \\
\text { fish farming helps to } \\
\text { maximized little } \\
\text { piece of land for } \\
\text { higher profit }\end{array}$ & $50(33.6)$ & $92(61.7)$ & $5(3.4)$ & $2(1.3)$ & 488 & 3.28 \\
\hline $\begin{array}{l}\text { Integrated rice and } \\
\text { fish farming can } \\
\text { help bridge the gap } \\
\text { between supply and } \\
\text { demand of fish }\end{array}$ & $55(36.9)$ & $84(56.4)$ & $4(2.7)$ & $6(4)$ & 486 & 3.26 \\
\hline $\begin{array}{l}\text { Integrated rice and } \\
\text { fish farming helps to } \\
\text { combat decline in } \\
\text { soil fertility }\end{array}$ & $59(39.6)$ & $73(49)$ & $12(8.1)$ & $5(3.4)$ & 484 & 3.25 \\
\hline $\begin{array}{l}\text { Integrating fish into } \\
\text { rice farm provide } \\
\text { additional means of } \\
\text { profit to rice farmers }\end{array}$ & $49(32.9)$ & $89(59.7)$ & $7(4.7)$ & $4(2.7)$ & 481 & 3.23 \\
\hline $\begin{array}{l}\text { Integrated rice and } \\
\text { fish farming helps to } \\
\text { solve the } \\
\text { underutilization of } \\
\text { water in rice } \\
\text { monoculture }\end{array}$ & $44(29.5)$ & $93(62.4)$ & $12(8.1)$ & $0(0)$ & 479 & 3.21 \\
\hline $\begin{array}{l}\text { Integrated rice and } \\
\text { fish farming reduce } \\
\text { the use of } \\
\text { herbicides }\end{array}$ & $42(28.2)$ & $92(61.7)$ & $15(10.1)$ & $0(0)$ & 474 & 3.18 \\
\hline $\begin{array}{l}\text { Rice integrated with } \\
\text { fish yield more profit } \\
\text { compare to rice } \\
\text { monoculture }\end{array}$ & $38(25.5)$ & $100(67.1)$ & $10(6.7)$ & $1(0.7)$ & 473 & 3.17 \\
\hline $\begin{array}{l}\text { Integrating fish with } \\
\text { rice farming can } \\
\text { increase rice yield }\end{array}$ & $44(29.5)$ & $88(59.1)$ & $12(8.1)$ & $5(3.4)$ & 469 & 3.15 \\
\hline $\begin{array}{l}\text { The stocked fishes } \\
\text { are capable of } \\
\text { devouring insect } \\
\text { pest of rice thereby }\end{array}$ & $44(29.5)$ & $87(58.4)$ & $14(9.4)$ & $4(2.7)$ & 469 & 3.15 \\
\hline
\end{tabular}


RICE FARMERS' PERCEPTION AND KNOWLEDGE OF INTEGRATED RICE AND FISH FARMING

\begin{tabular}{|c|c|c|c|c|c|c|}
\hline $\begin{array}{l}\text { reducing use of } \\
\text { pesticides }\end{array}$ & & & & & & \\
\hline $\begin{array}{l}\text { Integrated rice and } \\
\text { fish farming is an } \\
\text { efficient means of } \\
\text { utilizing farm } \\
\text { resources to } \\
\text { maximum capacity. }\end{array}$ & $44(29.5)$ & $89(59.7)$ & $9(6)$ & $7(4.7)$ & 468 & 3.14 \\
\hline $\begin{array}{l}\text { Integrated rice and } \\
\text { fish farming provide } \\
\text { employment to } \\
\text { household members }\end{array}$ & $38(25.5)$ & $96(64.4)$ & $13(8.7)$ & $2(1.3)$ & 468 & 3.14 \\
\hline $\begin{array}{l}\text { Little capital is } \\
\text { required to } \\
\text { implement } \\
\text { aquaculture on rice } \\
\text { fields }\end{array}$ & $28(18.8)$ & $88(59.1)$ & $26(17.4)$ & $7(4.7)$ & 435 & 2.92 \\
\hline $\begin{array}{l}\text { Integrated rice and } \\
\text { fish farming reduce } \\
\text { the cost of fertilizer }\end{array}$ & $30(20.1)$ & $79(53)$ & $37(24.8)$ & $3(2)$ & 434 & 2.91 \\
\hline $\begin{array}{l}\text { Integrated rice and } \\
\text { fish farming does } \\
\text { not improve house } \\
\text { hold food } \\
\text { consumption }\end{array}$ & $20(13.4)$ & $22(14.8)$ & $68(45.6)$ & $39(26.2)$ & 424 & 2.85 \\
\hline $\begin{array}{l}\text { There is increase in } \\
\text { commercial feeds } \\
\text { used for feeding fish }\end{array}$ & $36(24.2)$ & $47(31.5)$ & $63(42.3)$ & $3(2)$ & 414 & 2.78 \\
\hline $\begin{array}{l}\text { Integrated rice and } \\
\text { fish farming is ideal } \\
\text { mostly for wet } \\
\text { season rice farming }\end{array}$ & $32(21.5)$ & $58(38.9)$ & $50(33.6)$ & $9(6)$ & 411 & 2.76 \\
\hline $\begin{array}{l}\text { Integrated rice and } \\
\text { fish farming do not } \\
\text { allow rice to grow } \\
\text { well because fishes } \\
\text { feeds on rice plants }\end{array}$ & $27(18.1)$ & $40(26.8)$ & $70(47.0)$ & $12(8.1)$ & 365 & 2.45 \\
\hline $\begin{array}{l}\text { Integrated rice and } \\
\text { fish farming is } \\
\text { labour intensive }\end{array}$ & $37(24.8)$ & $96(64.4)$ & $12(8.1)$ & $4(2.7)$ & 281 & 1.89 \\
\hline $\begin{array}{l}\text { Fish can be stolen } \\
\text { or eaten by } \\
\text { predators, e.g. birds }\end{array}$ & $64(43)$ & $65(43.6)$ & $16(10.7)$ & $4(2.7)$ & 258 & 1.73 \\
\hline
\end{tabular}

Source: Field Survey, 2018; (SD = Strongly disagreed, $\mathrm{D}=$ Disagreed, $\mathrm{A}=$ Agreed, $\mathrm{SA}=$ Strongly agreed)

The result in Table 2 shows the respondents' perception towards integrated rice and fish farming. Result reveals that integrating rice and fish farming reduce waste disposal by recycling organic waste from fish for rice production has the highest mean score (M.S.=3.29). Little and Edwards 
(2003) noted that integrated farming helps to reduce the need for, and costs of external inputs by recycling available nutrients. This was followed by integrated rice and fish farming helps to maximize little piece of land for higher profit (M.S.=3.28).

Frei and Becker (2005) noted that integrating fish with rice production could help optimize resources through complementary use of land and water. Integrated rice and fish farming could help bridge the gap between supply and demand of fish (M.S.=3.26). Respondents agreed that integrated rice and fish farming improves house hold food (M.S.=2.85), it increases the cost of commercial feeds used for feeding fish (M.S.=2.78), and it is ideal mostly for wet season rice farming (M.S.=2.76). Going by the threshold of 2.5 adopted for this study, respondents had a negative perception of the following statements: fish can be stolen or eaten by predators (M.S.=1.73), integrated rice and fish farming is labour intensive (M.S.=1.89) and integrated rice and fish farming do not allow rice to grow well because fishes feed on rice plants (M.S.=2.45), this corroborates the findings of Longtau (2003), that rice farmers in Borno state considered Tilapia fish as a pest to rice seedlings. Although herbivorous fishes, such as Nile tilapia and common carp, completely destroys filamentous algae in rice plots, high density of such fishes could become detrimental to the rice plants (Frei and Becker 2005). Hence, the need to sensitize farmers on the type and quantity of fish to integrate with rice production.

Result as presented in Table 3 shows that $8.7 \%$ of the respondents had a mean score of less than 2.5.

Table 3 - Distribution of respondents based on their perception towards Integrated Rice and Fish Farming

\begin{tabular}{lll}
\hline Mean score & Frequency & Percentage \\
\hline$<2.5$ & 13 & 8.7 \\
\hline$\geq 2.5$ & 136 & 91.3 \\
\hline Total & $\mathbf{1 4 9}$ & $\mathbf{1 0 0}$ \\
\hline Minimum & $\mathbf{0 . 8 9}$ & \\
\hline Maximum & $\mathbf{3 . 3 5}$ & \\
\hline Mean & $\mathbf{3 . 0 4}$ & \\
\hline
\end{tabular}

Source: Field Survey, 2018; Bench mark $=2.5$, Decision rule: mean scores $<2.5=$ Negative perception and mean score $\geq 2.5=$ Positive perception.

This indicates a negative perception toward integrated rice and fish farming. On the other hand 91.3\% of the respondents had mean score greater than or equal to 2.5 hence a positive perception towards integrated rice and fish farming. Respondents' average mean score of perception is 3.04 suggests a favorable disposition of rice farmers to the practice of integrating fish with rice farming. This could be as a result of farmers' involvement in traditional practice of trapping fish in rice fields.

\section{Knowledge of Integrated Rice and Fish Farming among the respondents} This section discusses respondents' knowledge of integrated rice and fish farming. The results are as summarized in Table 4.

The result in Table 4 shows that 93.3\% of the respondent possessed high knowledge level of producing 


\section{RICE FARMERS' PERCEPTION AND KNOWLEDGE OF INTEGRATED RICE AND FISH FARMING}

fish either concurrently or alternatively with rice. Rasowo et al. (2008) noted

that rice fields in its aquatic phase is a rich potential fish ponds.

Table 4 - Respondents' knowledge of Integrated Rice and Fish Farming

\begin{tabular}{|c|c|c|}
\hline Knowledge item & $\begin{array}{l}\text { Knowledge } \\
(\%)\end{array}$ & $\begin{array}{l}\text { Knowledge } \\
\text { category }\end{array}$ \\
\hline $\begin{array}{l}\text { Integrated rice and fish farming allows fish to grow } \\
\text { concurrently or alternatively with rice }\end{array}$ & 93.3 & High \\
\hline $\begin{array}{l}\text { Waste and by-product from one subsystem are } \\
\text { used as input on the other subsystem }\end{array}$ & 89.3 & High \\
\hline $\begin{array}{l}\text { Presence of fish in the rice field boost rice field } \\
\text { fertility and lower fertilizer needs }\end{array}$ & 26.8 & Low \\
\hline $\begin{array}{l}\text { It is possible to achieve two cycles of fish } \\
\text { production in a year }\end{array}$ & 57.7 & Moderate \\
\hline $\begin{array}{l}\text { Stocking density should not be more than } 3500- \\
4000 \text { fingernails per hectare }\end{array}$ & 8.72 & Low \\
\hline $\begin{array}{l}\text { Organic nitrogen is higher in field with integrated } \\
\text { rice and fish }\end{array}$ & 66.4 & Moderate \\
\hline $\begin{array}{l}\text { Provision of deeper area as a refuge for the fish in } \\
\text { case of water loss }\end{array}$ & 48.3 & Low \\
\hline $\begin{array}{l}\text { Inorganic fertilizer are broadcasted on the soil } \\
\text { during land preparation }\end{array}$ & 38.5 & Low \\
\hline $\begin{array}{l}\text { The stocking period of fry is between the } \\
\text { transplanting period and first weeding }\end{array}$ & 31.5 & Low \\
\hline $\begin{array}{l}\text { Height of dike must be increased to allow deeper } \\
\text { water into the field to minimize the risk of flooding }\end{array}$ & 50.5 & Moderate \\
\hline $\begin{array}{l}\text { The stocking period for fingerlings is between } \\
\text { second weeding and flowering of rice }\end{array}$ & 43 & Low \\
\hline $\begin{array}{l}\text { Variety of rice used in integrated rice and fish } \\
\text { farming must have high tiller height and short } \\
\text { growing period }\end{array}$ & 35.6 & Low \\
\hline $\begin{array}{l}\text { Fertilizer can be broadcasted to aid the growth of } \\
\text { phytoplankton }\end{array}$ & 77.2 & High \\
\hline $\begin{array}{l}\text { Rice and fish culture is suitable for late reaping } \\
\text { rice }\end{array}$ & 76.5 & High \\
\hline $\begin{array}{l}\text { Selective harvesting of mature fish is possible in } \\
\text { integrated rice and fish farming }\end{array}$ & 75.8 & High \\
\hline $\begin{array}{l}\text { Weeding should not be done with the use of } \\
\text { herbicides }\end{array}$ & 73.8 & Moderate \\
\hline $\begin{array}{l}\text { Integrated rice and fish farming is ideal for long } \\
\text { stemmed rice varieties }\end{array}$ & 72.3 & Moderate \\
\hline $\begin{array}{l}\text { Water height of } 5.0-7.5 \mathrm{~cm} \text { is consider best for } \\
\text { optimum grain yield, nutrient supply and weed } \\
\text { control }\end{array}$ & 50.3 & Moderate \\
\hline $\begin{array}{l}\text { All fish species are not suitable for integrated rice } \\
\text { and fish farming }\end{array}$ & 53 & Moderate \\
\hline $\begin{array}{l}\text { Herbivorous fishes are suitable for integrated rice } \\
\text { and fish farming }\end{array}$ & 63.8 & Moderate \\
\hline
\end{tabular}


Also, $89.3 \%, 77.2 \%, 76.5 \%$ and $75.8 \%$ of the respondents possessed high knowledge level of the use of waste and by-product from one subsystem as input in the other subsystem, fertilizer can be broadcasted to aid the growth of phytoplankton, suitability of rice and fish culture for late reaping rice selective harvesting of mature fish is possibility of selective harvesting of mature fish le in integrated rice and fish farming. Farmers' high knowledge level could be attributed to the experience garnered through fishes deposited through flooding on their rice farms. Respondents also possessed moderate knowledge of the following: weeding should not be done with the use of herbicides (73.8\%), integrated rice and fish farming is ideal for long stemmed rice varieties $(72.3 \%)$, organic nitrogen is higher in field with integrated rice and fish (66.4\%) and herbivorous fishes are suitable for integrated rice and fish farming (63.8\%). Respondents possessed low knowledge of the following: stocking density should not be more than 3500 - 4000 fingernails per hectare $(8.72 \%)$, presence of fish in the rice field boost productivity and lower fertilizer needs (26.8\%), the stocking period of fry is between the transplanting period and first weeding (31.5\%), variety of rice used in integrated rice and fish farming must have high tiller height and short growing period (35.6\%), inorganic fertilizer are broadcasted on the soil during land preparation (38.5\%), and the stocking period for fingerlings is between second weeding and flowering (43.0). This result shows that farmers possessed low technical knowledge of integrated rice and fish farming and such knowledge cannot be acquired through experience but rather intensive training or workshops. Ahmed and Garnett (2011) affirms that rice farmers in Bangledesh were reluctant to involve in rice farming because of lack of technical knowledge. Also, Ahmed and Garnett (2011) opined that provision of institutional and organizational support, training facilities and extension services for sustainable rice-fish farming would help to increase the knowledge of farmers, improve profitability and reduce risks.

Table 5 - Distribution of respondents based on their knowledge level of Integrated Rice and Fish Farming

\begin{tabular}{lll}
\hline $\begin{array}{l}\text { Knowledge } \\
\text { Level }\end{array}$ & Frequency & Percentage \\
\hline High & 31 & 20.8 \\
\hline Moderate & 95 & 63.8 \\
\hline Low & 23 & 15.4 \\
\hline Total & $\mathbf{1 4 9}$ & $\mathbf{1 0 0}$ \\
\hline
\end{tabular}

Source: Field Survey, 2018; Decision rule: Scores $\geq 15$ points $=$ High knowledge, scores $\geq$ 10 points $<15$ points = Moderate knowledge and mean score $<10$ points = low knowledge.

Result in Table 5 shows that $20.8 \%$ of the respondents possessed high knowledge of integrated rice and fish farming, $63.8 \%$ of the respondents had moderate knowledge, while $15.4 \%$ of the farmers had low knowledge of integrated rice and fish farming. This result indicates that majority of the rice farmers (63.8\%) had moderate knowledge of integrated 


\section{RICE FARMERS' PERCEPTION AND KNOWLEDGE OF INTEGRATED RICE AND FISH FARMING}

rice and fish farming. This could be as a result of prior exposure to rice and fish farming through invasion of their rice fields by fishes. This result suggests that farmers possessed basic knowledge of integrating fish with rice production, which could be a foundation upon which further in-depth training could be built upon.

\section{Constraint to practice} Integrated Rice and Fish Farming

This section discusses the constraint to practice integrated rice and fish farming. The results are as summarized in Table 6.

Table 6 - Respondent's constraint to the practice of Integrated Rice and Fish Farming

\begin{tabular}{lllllll}
\hline Constraints & $\begin{array}{l}\text { Very } \\
\text { serious } \\
\mathbf{F ~ ( \% )}\end{array}$ & $\begin{array}{l}\text { Serious } \\
\mathbf{F}(\%)\end{array}$ & $\begin{array}{l}\text { Not a } \\
\text { constraint } \\
\mathbf{F ~ ( \% )}\end{array}$ & Score & M.S. & Rank \\
\hline $\begin{array}{l}\text { High cost of irrigation } \\
\text { material }\end{array}$ & $100(67.1)$ & $37(24.8)$ & $12(8.1)$ & 237 & 1.59 & $1^{\text {st }}$ \\
\hline $\begin{array}{l}\text { Poaching (stealing of } \\
\text { fish) }\end{array}$ & $102(68.5)$ & $33(22.1)$ & $14(9.4)$ & 237 & 1.59 & $1^{\text {st }}$ \\
\hline Flooding & $96(64.4)$ & $39(26.2)$ & $14(9.4)$ & 231 & 1.55 & 3 rd \\
\hline Water pollution & $91(61.1)$ & $33(22.1)$ & $25(16.8)$ & 215 & 1.44 & 4 th \\
\hline $\begin{array}{l}\text { Lack of technical } \\
\text { knowledge }\end{array}$ & $63(42.3)$ & $66(44.3)$ & $20(13.4)$ & 192 & 1.29 & 5 th \\
\hline Poor water quality & $66(44.3)$ & $58(38.9)$ & $25(16.8)$ & 190 & 1.28 & $6^{\text {th }}$ \\
\hline High production cost & $46(30.9)$ & $90(60.4)$ & $13(8.7)$ & 182 & 1.22 & $7^{\text {th }}$ \\
\hline High cost of labour & $42(28.2)$ & $93(62.4)$ & $14(9.4)$ & 177 & 1.19 & $8^{\text {th }}$ \\
\hline $\begin{array}{l}\text { Lack of government } \\
\text { support }\end{array}$ & $50(33.6)$ & $73(49)$ & $26(17.4)$ & 173 & 1.16 & $9^{\text {th }}$ \\
\hline $\begin{array}{l}\text { High cost of } \\
\text { fingerlings }\end{array}$ & $36(24.2)$ & $89(59.7)$ & $24(16.1)$ & 161 & 1.08 & $10^{\text {th }}$ \\
\hline $\begin{array}{l}\text { More intense than } \\
\text { monoculture }\end{array}$ & $32(21.6)$ & $71(47.3)$ & $46(31.1)$ & 135 & 0.91 & $11^{\text {th }}$ \\
\hline $\begin{array}{l}\text { Damage to rice by } \\
\text { stocked fish }\end{array}$ & $30(20.1)$ & $67(45)$ & $52(34.9)$ & 127 & 0.85 & $12^{\text {th }}$ \\
\hline
\end{tabular}

Source: Field Survey, 2018; M.S. = Mean score

Results presented in Table 6 show the level of severity of various constraints to practice of integrated rice and fish farming among rice farmers. Result reveals that the most severe constraints were high cost of irrigation materials and poaching (stealing of fish) with (M.S.= 2.59) and both were rated $1^{\text {st }}$. Flooding (M.S.=2.55) and water pollution (M.S.=2.44) were rated $2^{\text {nd }}$ and $3^{\text {rd }}$, respectively, as constraints faced by the rice farmers. Other constraints in order of severity were lack of technical knowledge (M.S.=2.29), poor water quality (M.S.=2.28), high production cost (M.S.=2.22), high cost of labour (M.S.=2.19), lack of government support (2.16), high cost of fingerlings (2.08) and more intense than monoculture (1.91). The least constraint to integrated rice and first 
farming was damage to rice by stocked fish (1.85). The result also reveal that the constraints that were identified as severe were poaching (stealing of fish), flooding, water pollution and lack of technical knowledge.

Results presented in Table 7 shows the correlation analysis between some selected socio economic characteristics of farmers and their knowledge level of integrated rice and fish farming. Results show that age of the respondents $(\mathrm{r}=0.300, p<0.000)$, level of education $(\mathrm{r}=0.287, \quad p<0.000)$, farming experience $(\mathrm{r}=0.220$, $p<0.007$ ), membership of cooperative society $\quad(r=0.176, \quad p<0.032) \quad$ and frequency of extension contact $(\mathrm{r}=0.204, \quad p<0.013)$ had significant relationship with knowledge level of farmers. The positive relationship between age of respondent and knowledge level implies that as the age of respondent increases their knowledge level of integrated rice and fish farming will increase, that is increase in age will equal to increase in knowledge of integrated rice and fish farming. This implies that young farmers would be more receptive to trainings on integrated rice and fish farming. Similarly, Sharma and Kendra (2016) reported a positive correlation between age of dairy farmers and their knowledge of dairy practices. They found out that young people were more interested in acquiring knowledge through trainings and demonstrations.

Table 7 - Correlation analysis showing the relationship between selected socio-economic characteristics of farmers and knowledge level of Integrated Rice and Fish Farming

\begin{tabular}{llll}
\hline Socio-economic characteristics & $\boldsymbol{r}$ - value & $\boldsymbol{p}$ - value & Decision \\
\hline Age & $0.300^{* *}$ & 0.000 & Significant \\
\hline Sex & -0.188 & 0.122 & Not significant \\
\hline Level of education & $0.287^{\star *}$ & 0.000 & Significant \\
\hline Farm size & 0.025 & 0.760 & Not significant \\
\hline Family size & -0.158 & 0.054 & Not significant \\
\hline Farming experience & $0.220^{* *}$ & 0.007 & Significant \\
\hline Primary occupation & -0.119 & 0.147 & Not significant \\
\hline Membership of cooperative society & $0.176^{* *}$ & 0.032 & Significant \\
\hline Extension contact & $0.204^{* *}$ & 0.013 & Significant \\
\hline
\end{tabular}

Source: Field survey, 2018; ${ }^{*}$ Significant at the 0.05 level (2-tailed).

Similarly, the positive relationship between level of education and knowledge level implies that the higher the educational status of the respondent the higher the knowledge of integrated rice and fish farming. Uddin et al. (2017) also affirm that educational status is one of the determinants of farmers' knowledge of modern rice cultivation in Bangladesh. Also, Kaur et al. (2017) reported that education had a significant effect on the overall knowledge score of dairy farm 
women on various farming practices. Such that women with higher educational qualification had higher knowledge score, as compared to women with lower educational qualification.

Farming experience had a positive relationship on the knowledge level of rice farmers. The higher the years of farming, the higher the knowledge about integrated rice and fish farming and there was also a positive relationship between membership of cooperative societies and knowledge level. This implies that if a farmer is a member of a cooperative society there will be increase in knowledge of integrated rice and fish farming. Kolade and Harpham (2014) asserted that cooperative societies are more auspicious platform for quick dissemination of information and also more efficient for extension workers and technology sellers to link up with and train groups of farmers rather than individuals. Lastly, there was a positive relationship between frequency of extension contact and knowledge of integrated rice and fish farming. The higher the number of extension contacts, the higher the knowledge of integrated rice and fish farming. However, sex $(\mathrm{r}=-0.188$, $p<0.022)$, farm size $(\mathrm{r}=0.025, p<0.760)$, family size $(\mathrm{r}=-0.158, p<0.054)$ and primary occupation $(\mathrm{r}=-0.119$, $p<0.147$ ) did not have a significant relationship with respondents' knowledge of integrated rice and fish farming.

Table 8 - Result of the correlation analysis between farmers' knowledge level and their perception towards Integrated Rice and Fish Farming

\begin{tabular}{ccc}
\hline & $\begin{array}{c}\text { Knowledge } \\
\text { level }\end{array}$ & $\begin{array}{c}\text { Perception towards Integrated } \\
\text { Rice and Fish Farming }\end{array}$ \\
\hline Knowledge level & 1 & $0.194^{* *}$ \\
\hline $\begin{array}{c}\text { Perception towards Integrated } \\
\text { Rice and Fish Farming }\end{array}$ & $0.194^{* *}$ & 1 \\
\hline
\end{tabular}

Source: Field survey, 2018. ${ }^{* *}$ Correlation is significant at the 05 level (2-tailed).

Table 8 shows the result of correlation analysis of the relationship between knowledge level and perception of rice farmers towards integrated rice and fish farming. Result shows that perception of farmers had a positive relationship on the knowledge level of rice farmers. The higher the perception the higher their knowledge of integrated rice and fish farming.

\section{CONCLUSIONS AND RECOMMENDATIONS}

The study concluded that rice farmers possessed positive perception and moderate knowledge of integrated rice and fish farming. High cost of irrigation material and lack of technical knowledge were identified as some of the constraints to the practice of integrated rice and fish farming. Respondents' age, level of education, farming experience, 
membership of cooperative society were positively correlated with their knowledge level. Based on these findings, this study recommends the training of rice farmers on the technical aspects of integrating rice with fish production and also farmers should be sensitized on the importance of membership of cooperative societies in terms of access to credit and information.

\section{REFERENCES}

Abdul-Gafar, A., Xu, S.W. \& Yu, W. (2016). Perceptions of rice farmers towards production constraints: case study of Niger State of Nigeria and Hainan of China. J.Agric.Chem. Environ., 5(1B): 20-30, DOI: 10.423 6/jacen.2016.51B004

Adekoya, O.A. (2014). Analysis of frarm households poverty status in Ogun State, Nigeria. Asian Econ.Fin. Rev., 4(3), 325-340, http://aessweb.com/ journal-detail.php?id=5002

Adesope, O.M., Matthews-Nkoju, E.C., Oguzor, N.S. \& Ugwuja, V.C. (2012). Effect of socio-economic characteristics of farmers on their adoption of organic farming practices. In: Peeyush Sharma and Vikas Abrol (Eds.), Crop Production Technologies, pp. 212-220, Intech Open DOI: $10.5772 / 30712$

Agyeman, B.A.S., Asuming-Brempong, S. \& Onumah, E.E. (2014). Determinants of income diversification of farm households in the Western Region of Ghana. Q.J.Int.Agric., 53(1): 55-72, DLGVerlag Frankfurt/M, DOI: 10.22004/ ag.econ.195729

Ahmed, N. \& Garnett, S.T. (2011). Integrated rice-fish farming in Bangladesh: meeting the challenges of food security. Food Security: the science, sociology and economics of food production and access to food,
3(1): 81-92, Springer Netherlands, DOI: $10.1007 / \mathrm{s} 12571-011-0113-8$

Ayinde, O.E., Bello, K.A. \& Ajewole, O.O. (2016). The evaluation of risk attitude of rice farmers in Kwara State, Nigeria. AJPAS, 3: 1-5.

Ellis, F. (2000). The determinants of rural livelihood diversification in developing countries. J.Agric.Econ., DOI: 10.1111/j.1477-9552.2000.tb01 229

Enimu, S. (2018). Economic analysis of poverty status of small-scale farmers in Bayelsa State, Nigeria. CIACR, DOI: $10.32474 / C I A C R .2018 .04 .000$ 199

Fakayode, S., Omotesho, O.A. \& Omoniwa, A.E. (2010). Economic analysis of rice consumption patterns in Nigeria. J.Agric.Sci. Technol., Tarbiat Modares University Press, 12(2): 135-144.

Frei, M. \& Becker, K. (2005). A greenhouse experiment on growth and yield effects in integrated ricefish culture. Aquaculture, DOI: 10.1111/j.1477-8947.2005.00122.x

Gabriel, U.U., Akinrotimi, O.A., Bekibele D.O., Anyanwu, P.E. \& Onunkwo, D.N. (2007). Economic benefit and ecological efficiency of integrated fish farming in Nigeria. Sci.Res. Essays, 2(8): 302-308, http://www. academicjournals.org/SRE

Kaur, S., Verma, H.K., Singh, J., Dash, S.K. \& Kansal, S.K. (2017). Knowledge level of women dairy farmers about various farming practices in border area of Punjab. J.Anim.Res., 7(6): 1051-1056, DOI: 10.5958/2277-940X.2017.00157.7

Kolade, O. \& Harpham, T. (2014). Impact of cooperative membership on farmers' uptake of technological innovations in Southwest Nigeria. Dev.Stud.Res., 1(1): 340-353, DOI: 10.1080/21665095.2014.978981

Little, D.C. and Edwards, P. (2003). Integrated Livestock Fish Farming Systems. Food and Agriculture Organisation. Rome, Italy. ISBN 9251050554. 


\section{RICE FARMERS' PERCEPTION AND KNOWLEDGE OF INTEGRATED RICE AND FISH FARMING}

Longtau, S.R. (2003). Multi-agency partnership for technical change in West Africa agriculture: Nigeria case study report on rice production. Ecosystems Development Organisation (EDO) for Overseas Development Institute (ODI), http://www.odi.org.uk /sites/odi.org.uk/files/odiassets/publi cations-opinion-files/3986.pdf

National Bureau of Statistics (2018). Demographic statistics bulletin. https://nigerianstat.gov.ng. Accessed on $23^{\text {rd }}$ July 2019.

Odetola, T. \& Etumnu, C. (2013). Contribution of agriculture to economic growth in Nigeria. To be presented at: The $18^{\text {th }}$ Annual Conference of the African Econometric Society (AES) Accra, Ghana at the session organized by the Association for the Advancement of African Women Economists (AAAWE), $22^{\text {nd }}$ and $23^{\text {rd }}$ July, 2013.

Oladimeji, Y.U. \& Abdulsalam, Z. (2013). Analysis of technical efficiency and its determinants among small scale rice farmers in Patigi local government area of Kwara State, Nigeria. IOSR-JAVS, 3(3): 34-39, DOI: 10.9790/2380-0333439

Omotesho, K.F., Ogunlade, I., Akinrinde, A.F. \& Omotayo, R.O. (2017), Farmers' Perception of Dry Season Rice Farming in Edu Local Government Area of Kwara State, Nigeria. International Journal of Tropical Agriculture Research and Extension, 20(1\&2): 21-31.

Oribhabor, B.J. \& Ansa, E.J. (2006). Organic waste reclamation, recycling and re-use in integrated fish farming in the Niger Delta. J.Appl.Sci. Environ.Mgt., 10(3): 47-53, DOI: 10.4314/jasem.v10i3.17319
Oyekale, A.S., Adepoju. A.O. \& Balogun, A.M. (2012). Determinants of poverty among riverine rural households in Ogun State, Nigeria. Studies of Tribes and Tribals. DOI: 10.1080/0972639x.2012.11886647

Rahman, M.A. (2016). Integration of aquaculture with rice farming: A way to increase farm productivity, food security, livelihood improvement and better environment. $6^{\text {th }}$ International Conference in Agriculture, Environment and Biological Sciences, December $21^{\text {st }}$ $22^{\text {nd }}$,Malaysia. DOI: $10.15242 / I E . A$ 1216044

Rasawo, J., Auma, E., Ssanyu, G. \& Ndunguru, M. (2008). Does African catfish (Clarias gariepinus) affect rice in integrated rice-fish culture in Lake Victoria basin, Kenya ? Afr.J. Env.SciTechnol., 2(10): 336-341.

Sharma, M. \& Kendra, V. (2016). Effect of age and educational level of dairy farmers on knowledge and adoption of dairy farming practices in Kapurthala district of Punjab. Int.J. Farm Sci., 6(4): 254-262.

Uddin, J., Masum Billah, K.M., Akanda, G.R., Prince, M.H., Rahma, M.M., Sumon, M.P. \& Antor, N.H. (2017). Farmers' knowledge on modern rice cultivation techniques at Dumki Upazilla. IJAAS, 2(10): 01-07.

Vromant, N., Duong, L.T. \& Ollevier, F. (2002). Effect of fish on the yield and yield component of rice in integrated concurrent rice-fish systems. J.Agric. Sci., 138(1): 63-71, Cambridge University Press, DOI: 10.1017/S00 21859601001642

World Bank (2017). Nigeria country overview. http://www.worldbank.org/ en/country/nigeria/overview accessed on $12^{\text {th }}$ July, 2019. 